\title{
Serological detection of hepatitis B and D virus co-infection among patients attending a tertiary health facility at Maiduguri, Nigeria
}

Babajide B. Ajayi ${ }^{1}$, Semsari Latbone ${ }^{2}$, Iman U. Igwegbe², Ibrahim M. Kida ${ }^{3}$, Babagana W. Goni Oyebode O. Samuel ${ }^{4}$, Joshua S. Dawurung ${ }^{5}$, Hamidu M. Ibrahim ${ }^{6}$, Ballah A. Danue ${ }^{3}$, Idris Nasir Abdullahi ${ }^{7^{*}}$ (D) and Bamidele S. Oderinde ${ }^{2}$

\begin{abstract}
Background: Hepatitis D virus (HDV) is highly pathogenic, and clinical studies revealed that HDV infection aggravates the natural history of the underlying hepatitis B virus (HBV) infection by progression to cirrhosis that leads to early decompensation of liver function compared with HBV mono-infection. To determine the seroprevalence of HDV among HBsAg-seropositive patients and associated biochemical profiles at Maiduguri, Nigeria, a hospital-based cross-sectional study on 180 sera of patients positive for HBsAg by ELISA were evaluated for anti-HDV, hepatitis B envelop antigen, anti-HBs antibodies and liver enzyme profiles.

Results: HDV seroprevalence of 3.3\% among $180 \mathrm{HBsAg-positive} \mathrm{patients.} \mathrm{Relatively} \mathrm{higher} \mathrm{seroprevalence} \mathrm{of}$ HDV was observed in males (4.3\%) than in females (2.3\%). The highest infection rate (20\%) was obtained in patients $\geq 56$ years. However, no significant association between positive anti-HDV seroprevalence and gender ( $p>0.05)$. Of the $6(3.3 \%)$ anti-HDV-positive patients, only 1 (16.7\%) was positive for HBeAg while all were negative for anti-HBs antibodies. The mean level of liver enzyme level of AST and ALT of the anti-HDVpositive patients significantly differ from that of HBsAg mono-infected patients ( $p$ < 0.05). However, no significant difference $(p<0.05)$ between the mean levels of liver enzymes of ALP in anti-HDV-positive and HBsAg mono-infected patients ( $p>0.05$ ) was found.

Conclusion: This study revealed a relatively low presence of HDV in HBsAg-positive patients. Furthermore, HDV-HBV co-infected patients had somewhat worse liver enzyme upregulation. This underscores the need for rapid HDV testing and treatment in HBV-infected patients.
\end{abstract}

Keywords: Hepatitis D virus, HDV-HBV co-infection, Seroprevalence, Nigeria

\footnotetext{
* Correspondence: eedris888@yahoo.com

${ }^{7}$ Department of Medical Laboratory Science, College of Medical Sciences,

Ahmadu Bello University, Zaria, Nigeria

Full list of author information is available at the end of the article
}

\section{Springer Open}

(c) The Author(s). 2021 Open Access This article is licensed under a Creative Commons Attribution 4.0 International License, which permits use, sharing, adaptation, distribution and reproduction in any medium or format, as long as you give appropriate credit to the original author(s) and the source, provide a link to the Creative Commons licence, and indicate if changes were made. The images or other third party material in this article are included in the article's Creative Commons licence, unless indicated otherwise in a credit line to the material. If material is not included in the article's Creative Commons licence and your intended use is not permitted by statutory regulation or exceeds the permitted use, you will need to obtain permission directly from the copyright holder. To view a copy of this licence, visit http://creativecommons.org/licenses/by/4.0/. 


\section{Background}

The hepatitis D (Delta) virus (HDV), which was discovered late in the 1970s, is the smallest virus of human virology. Hepatitis B virus (HBV) infection is a public health problem, and it is estimated globally that 248 to 292 million people are HBV chronically infected [1, 2]. Based on this estimation, about $5 \%$ of these patients were initially assumed to be HDV co-infected [3]. However, these figures are contrary to the findings of a recent meta-analysis that revealed an overwhelming 13 to $14 \%$, which corresponds to about 62 to 72 million people living with HDV worldwide $[4,5]$. This implies that a disease burden due to HDV could be much higher than previously considered [6]. Indeed, for decades, the exact global prevalence of HDV infection remains indefinite because of the varied and absence of standardised screening practices of HBV-positive patients for HDV and the inaccessibility to testing in many endemic and resource-constrained countries.

The HDV is currently described as the most severe and rapidly progressive form of chronic viral hepatitis regardless of being an imperfect virus that needs the presence of hepatitis B virus (HBV) to be a human pathogen [7, 8]. HDV is a small circular positive singlestranded RNA virus of $1.7 \mathrm{~kb}$ in size and the only representative of the Deltaviridae family, satellite of HDV relying on HBV surface protein HBsAg expression to produce new infectious particles [9]. There is a significantly poor prognosis in HDV co- or super-infected persons with chronic hepatitis B $[10,11]$. During infection, anti-delta antibodies appear in serum and can be detected by enzyme-linked immunosorbent assay (ELISA).

Since HDV requires HBV for its infectivity, it is also called a defective pathogen. The other important feature distinguishing HDV from other satellite viruses is its ability to replicate [12] independently. It is thought that the mechanism of HDV infection's damage to the liver is immune-mediated along with cytopathic effects. There are still unenlightened aspects of its pathogenesis. HDV infection is defined as co-infection or super-infection based on the condition of accompanying HBV infection [13].

The clinical and biochemical features of such infections resemble those of acute hepatitis alone [13] but may be more severe. Although the acute clinical presentations of a co-infection and super-infection are indistinguishable, the long-term sequelae differ markedly. Super-infection is more severe because a large number of hepatocytes are already producing HBsAg, and HDV can replicate without delay with a relatively short incubation period. It leads to severe liver damage, fulminant HBsAg-positive hepatitis and elevated mortality (up to $20 \%$ ) but most often results in chronic HDV infection [14].
Because HDV infection aggravates the natural history of the underlying HBV infection by progression to cirrhosis that leads to early decompensation of liver function compared with HBV mono-infection, this study aims to determine the seroprevalence of HDV in HBsAg-positive patients and associated liver biochemical profiles among the subjects.

\section{Methods}

\section{Study design}

This was a hospital-based cross-sectional study conducted between 20 April and 30 October 2019.

\section{Study area}

The study was carried out in the Department of Immunology of a tertiary health facility in North-eastern Nigeria. It is a designated centre of excellence in immunology and infectious diseases. The facility is a five hundred and thirty-bed capacity providing health services to the States in the northeast and also the neighbouring African countries such as Niger, Chad and Cameroon.

\section{Study population}

A total of $180 \mathrm{HBsAg-positive} \mathrm{samples} \mathrm{by} \mathrm{enzyme-}$ linked immunosorbent assay (ELISA) collected from patients sent for HBsAg investigation were evaluated for the presence of HDV, hepatitis Be antigen ( $\mathrm{HBeAg}$ ) and hepatitis B surface antibodies (HBsAb), and their liver enzyme profiles were also determined in the Immunology Department of the hospital (Table 1). The participants include 94 males and 86 females with an age range of $18-65$ years.

\section{Subject selection criteria}

We evaluated the prevalence of $\mathrm{HDV}$ in the HBVinfected subjects by screening all consecutive patients from 20 May to 30 July October 2019 (10 weeks). The inclusion criteria were $\mathrm{HBsAg}$ positive for at least the previous 6 months, seronegative test for HCV and HIV antibodies, do not consume alcohol and not received any antiviral or antimicrobial therapies. These data were gotten through a face-to-face interview of participants and confirmed from their physicians and hospital files.

\section{Sample size}

Being a cross-sectional study, the minimum sample size was determined by the expression:

$$
\frac{n=\mathrm{Z}^{2} \mathrm{Pq}}{d^{2}}
$$

$P=$ prevalence rate from a previous study at $Z=3.94$ and standard error of 0.05 . Using the prevalence of $4.9 \%$ 
Table 1 Age and gender distribution of HDV infection among HBsAg-positive patients

\begin{tabular}{|c|c|c|c|c|c|}
\hline \multirow{2}{*}{$\begin{array}{l}\text { Age } \\
\text { range } \\
\text { (years) }\end{array}$} & \multirow{2}{*}{$\begin{array}{l}\text { Number } \\
\text { tested }\end{array}$} & \multicolumn{2}{|l|}{ Male } & \multicolumn{2}{|l|}{ Female } \\
\hline & & Number tested & Number positive (\%) & Number tested & Number positive (\%) \\
\hline $18-25$ & 39 & 19 & 0 & 20 & 1 \\
\hline $26-35$ & 81 & 36 & 1 & 45 & 1 \\
\hline $36-45$ & 43 & 29 & 2 & 14 & 0 \\
\hline $46-55$ & 12 & 8 & 0 & 4 & 0 \\
\hline$\geq 56$ & 5 & 2 & 1 & 3 & 0 \\
\hline Total & 180 & 94 & 4 & 86 & 2 \\
\hline
\end{tabular}

Male: $X^{2}=12.162, p=0.016$; female: $X^{2}=1.132, p=0.889 ;$ gender: $X^{2}=5.215, p=0.266$

of HBV/HDV co-infection in a similar study in Nigeria [14], a minimum sample size of 73 was calculated. However, 180 subjects who voluntarily consented for participation were enrolled.

\section{Analytical laboratory methods}

The serum samples stored at $-20{ }^{\circ} \mathrm{C}$ were retrieved and thawed once at room temperature and were screened for the presence of HDV IgM, HBeAg and HBsAb by enzyme-linked immunosorbent assay (ELISA) (Diagnostic Automation/Cortez Diagnostics Inc., Calabasas, USA), and the liver enzyme profile was also determined using Roche/Hitachi 902 Chemistry Autoanalyser. The aspartate (ALT) and alanine amino transaminase (AST) were determined by the spectrophotometric method of Bergmeyer et al. [15] while alkaline phosphatase (ALP) was determined by the spectrophotometric nitrophenol method of Tietz et al. [16]. Per run and daily quality control for all laboratory procedures were ensured.

Physiological range values for liver enzyme activities in the blood [16]:

a. Alanine transaminase 0 to $45 \mathrm{IU} / \mathrm{L}$

b. Aspartate transaminase 0 to $35 \mathrm{IU} / \mathrm{L}$

c. Alkaline phosphatase 30 to $120 \mathrm{IU} / \mathrm{L}$

\section{Statistical analysis}

Statistical Package for Social Sciences version 23 (SPSS version 16.0 Inc., Chicago, IL, USA) was used for all analyses. A two-tailed chi-squared test was used to determine the possible significant association between sociodemographic variables of subjects and seroprevalence of HDV, while the Student $T$ test was used to determine the mean difference of continuous variables between the two groups (i.e. co-infected and monoinfected; $p$ values $<0.05$ at $95 \%$ confidence interval for all tests were considered statistically significant).

\section{Results}

About $8.9 \%$ of the HBsAg-positive patients were reactive for $\mathrm{HBeAg}$ while $16.1 \%$ were reactive for $\mathrm{HBsAb}$ (Table 2). All the HDV positives were also $\mathrm{HBsAb}$ negative, while 1 was positive for $\mathrm{HBeAg}$.

Table 3 shows the gender distribution of $\mathrm{HBeAg}$ and $\mathrm{HBsAb}$ in HBsAg-positive patients, indicating 6 and 10 were $\mathrm{HbeAg}$ reactive for female and male, respectively, while 18 and 11 were $\mathrm{HBs} A b$ reactive for female and male, respectively.

Table 4 shows the liver enzyme profiles among the HDV-positive patients where AST and ALT were elevated for HDV-positive patients and the mean values higher than in negative patients.

\section{Discussion}

Our results revealed a seroprevalence of 3.3\% (6/180) HDV infection among HBsAg-positive patients in Maiduguri, Borno State, North-eastern Nigeria (Fig. 1). The prevalence of 12.3 to $41 \%$ of HBsAg varies from several studies carried out among different populations in Maiduguri, Nigeria, which has revealed endemicity for HBsAg [17]. However, this is the first study on HDV infection among HBsAg-positive patients in this environment as hepatitis $\mathrm{D}$ virus screening is not normally carried out for blood donors or demanded as a followup test for HBsAg-positive patients knowing quite well that the environment is endemic for HBV. Our study

Table 2 Hepatitis B antigenemia among study population among hepatitis D-positive patients

\begin{tabular}{|c|c|c|c|c|c|c|}
\hline \multirow{2}{*}{$\begin{array}{l}\text { Tests } \\
\text { Anti-HDV }\end{array}$} & \multicolumn{3}{|l|}{ HBsAb } & \multicolumn{3}{|l|}{ HBeAg } \\
\hline & Positive & Negative & Total & Positive & Negative & Total \\
\hline Positive & $0(0)$ & $6(0)$ & $6(100)$ & 1 (16.7) & $5(83.3)$ & $6(100)$ \\
\hline Negative & $29(100)$ & $145(16.0)$ & $174(80.6)$ & 15 (8.6) & 159 (91.4) & $174(100)$ \\
\hline Total & $29(16.1)$ & 151 (83.9) & $180(100.0)$ & $16(8.9)$ & 164 (91.1) & $180(100)$ \\
\hline
\end{tabular}


Table 3 Hepatitis Be antigen and hepatitis surface antibody positivity and gender among hepatitis B surface antigenpositive patients

\begin{tabular}{llllll}
\hline Gender & HBeAg & & & HBsAb & \\
\cline { 2 - 3 } & Positive & Negative & & Positive & Negative \\
\hline Female & $6(7.0)$ & $80(93.0)$ & & $18(21.0)$ & $68(79.0)$ \\
Male & $10(11.0)$ & $84(89.0)$ & & $11(12.0)$ & $83(88.0)$ \\
Total & $16(8.9)$ & $164(91.1)$ & & $29(16.1)$ & $151(83.9)$ \\
\hline
\end{tabular}

revealed the prevalence of $3.3 \%$ of $\mathrm{HDV}$ antibodies among HBsAg-positive patients. However, the finding is higher than the postulated global prevalence of $0.82 \%$ [18]. This finding agrees with a similar study in the Northcentral region of Nigeria that showed a prevalence of $2.7 \%$ among HBsAg-positive individuals [19]. Our result is lower than those from the Southwest region with the prevalence of 1.1 to $6.5 \%$ co-infection of HBV/HDV $[14,20,21]$ and Northwest region of Nigeria with 5.43\% [22], respectively. Furthermore, our finding of 3.3\% was closely similar to the report in Khartoum, Sudan, with $2.8 \%$ (5/178) HDV IgM antibodies among blood donors [23] and lower than finding among blood donors in Egypt with 4.7\% (8/170) of HDV IgG [24]. Studies in Cameroon reported findings of 7-62\% HDV seroprevalence depending on the population studied and the assay used for the screening [25, 26]. Our result differs from several studies carried out in Gabon between administrative provinces, displaying prevalence of above $20 \%$ to above $60 \%$ anti-HDV among HBsAg-positive populations, confirming a pattern of high HDV seroprevalence suspected throughout the region [26-28].

Our study is in agreement with the finding in Jordan and Saudi Arabia who reported the prevalence of $2 \%$ and $3.3 \%$, respectively, and lower than the reports from Turkey and Kuwait with the prevalence of $5.2 \%$ and $31 \%$, respectively, of HDV infection among asymptomatic carriers of HBsAg [29]. The disease is not routinely diagnosed in Nigeria. HDV remains of significant

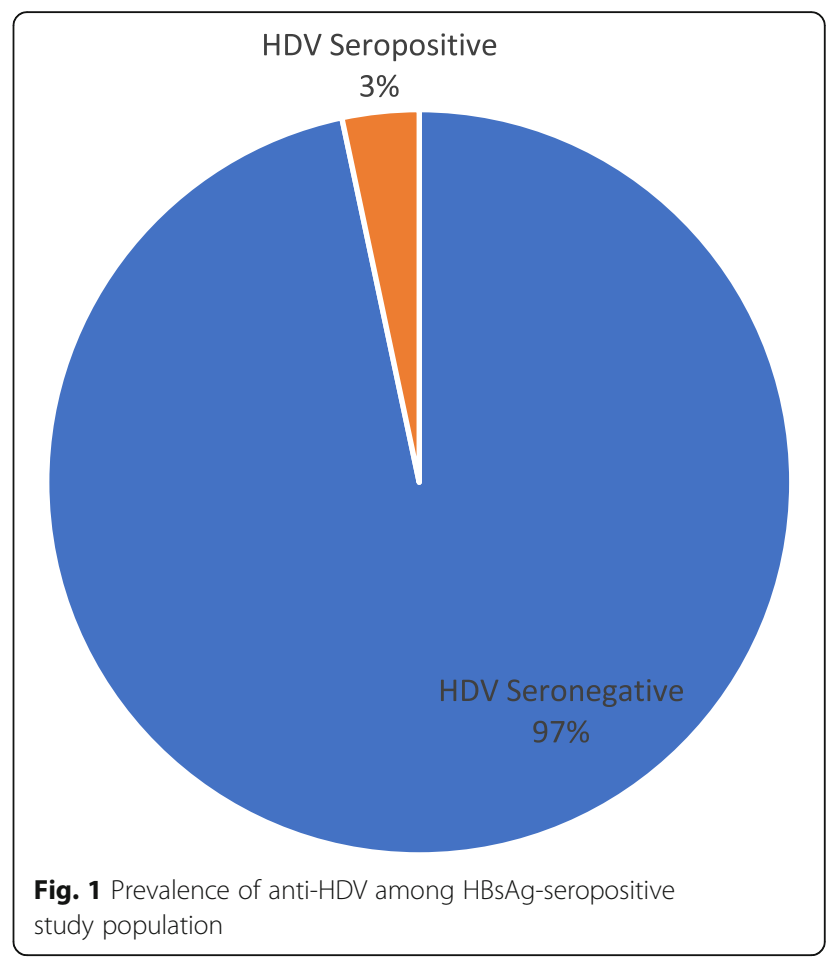

concern in any region where HBV is endemic [30]. Consequently, this should be considered a public health problem in Nigeria.

Our study revealed the male predominance of $4.3 \%$ (4/94) males while females $2.3 \%$ (2/86). Our finding was in agreement with the study carried out in southwestern Nigeria which showed males to be more predominant with HDV prevalence of $64.7 \%$ and $35.3 \%$ among the male and female gender, respectively [20]. This is also comparable with the study from Southeastern Nigeria [31] that showed the prevalence of $13.0 \%$ and $10.5 \%$ in males and females, respectively, and that of the North-western region that reported gender prevalence of $13.0 \%$ for males and $10.5 \%$ for females [22]. However, this distracts from the findings

Table 4 Liver enzyme profiles among hepatitis D antibody-seropositive patients

\begin{tabular}{|c|c|c|c|c|c|}
\hline Tests & Status & Number & Standard deviation (IU/L) & Mean (IU/L) & $p$ value \\
\hline \multirow[t]{3}{*}{ AST } & High & 6 & 2.0463 & 115.79039 & \\
\hline & Normal & 174 & 78.9586 & 99.98081 & \\
\hline & Total & 180 & 102.70039 & 102.87231 & 0.003 \\
\hline \multirow[t]{3}{*}{ ALT } & High & 6 & 1.2360 & 108.87231 & \\
\hline & Normal & 174 & 61.2736 & 75.68687 & \\
\hline & Total & 180 & 63.3511 & 77.47737 & 0.052 \\
\hline \multirow[t]{3}{*}{ ALP } & High & 6 & 1.6032 & 97.87846 & \\
\hline & Normal & 174 & 1.0216 & 77.17290 & \\
\hline & Total & 180 & 1.0411 & 78.32119 & 0.074 \\
\hline
\end{tabular}


at Benue in Northcentral, Nigeria, in which only women were HDV infected [19].

Our finding was in agreement with findings in Egypt $[32,33]$ and in Khartoum where males were more frequently infected by HDV, based on the results by ELISA and nested RT-PCR which are highly sensitive and specific assay procedures for detection of HDV [23]. This finding is in concordance with a report in Northern Vietnam which showed that more than $75 \%$ of HDVinfected patients were males among treatment-naive HBsAg-positive patients [34]. Our study was also in conformity with that of Andrade et al. [35] in the Western Brazilian Amazon, where they reported a prevalence that is significantly higher in males than female subjects. Our finding and the former results may be elucidated by the increased risk factors for viral infection among the male gender. Our findings showed that age range $\geq 56$ years were the patients most infected by HDV. This is in agreement with the study in Cameroon and Mauritania in which people ' 33 years old were the most affected population $[28,36]$. They attributed it to possibly due to nosocomial transmission during the early twentieth century in a study conducted in Cameroon [37].

In our study, $16.1 \%$ were reactive for $\mathrm{HBsAb}$ signifying prior immunity, while $83.9 \%$ were non-reactive signifying susceptibility to HBV infection. This is lower than the finding in Brazil among persons of high social vulnerability [38]. In the present study, of the 6 anti-HDVpositive patients, only $16.7 \%$ was positive for $\mathrm{HBeAg}$, while $83.3 \%$ were negative. Other studies have shown comparable findings with up to $90 \%$ of HDV-positive patients having negative $\mathrm{HBeAg}$ in Tunisia [33, 39]. This could be possibly due to a high rate of pre-core region mutations, which could have led to $90 \%$ of the Tunisian patients infected chronically with HBV [40, 41].

Furthermore, it has been described that HDV obstructs the expression of HBeAg through its ribozymes, which are enzymes that can destroy mRNAs and encode for the Pre/C region [42]. Furthermore, none of the positive anti-HDV was positive for HBsAb. This is in agreement with the report of Chun-Hua et al. [43] where the authors reported that of the $64 \mathrm{HBsAb}$-positive patients none was positive for anti-HDV. However, HBV is usually transmitted horizontally by blood products or mucosal contact. In highly endemic areas like Southeast Asia or Equatorial Africa, the most common mode of transmission is vertical transmission perinatally from an HBV-infected mother to the newborn child [44-46]. Certain types of behaviours increase the risk for contracting HBV which include the use of contaminated needle during acupuncture, intravenous drug abuse, ear piercing and tattooing, sexually active heterosexuals or homosexuals (for the last 6 months), infants/children in highly endemic areas, infants born to infected mothers, health care workers, haemodialysis patients and blood receivers (blood transfusion) as HDV Screening is not included in donor and blood banking, hemophilias, prisoners with long-term sentences and visitors to highly endemic regions [45]. In this study area, the use of some sharp objects for barbing and nail cutting might be a usual source of transmission.

Some epidemiological studies have shown that additional infection with HDV infection increases the progression rate to liver diseases in affected individuals [47]. Moreover, despite varying degrees of histological damage, some chronic hepatitis patients could have normal laboratory parameters [48]. However, in contrast to speedy liver decompensation by HBV/HDV infection, a study by Lago et al. [49] revealed the median HBV viral load in HBV/HDV co-infected individuals was slightly lower compared to the HBV mono-infected group, despite the lack of statistical significance. Reduced HBV viral load in HDV co-infected individuals has been previously reported by others as a potential inhibitory role of HDV over HBV replication at the intrahepatic level [50].

The presence of hepatitis B e-antigen ( $\mathrm{HBeAg}$ ) usually indicates active hepatitis $B$ virus (HBV) replication and high infectivity which is higher in male $11 \%$ than in female $7 \%$. Anti-HBs antibodies indicate that a person is protected against the hepatitis B virus. This protection can be the result of receiving the hepatitis $B$ vaccine or successfully recovering from a past hepatitis B infection. The female is $21 \%$ which is higher than the male $12 \%$. This result might be related to studies illustrating the physiological difference between sex difference in responses to HBV infection. Females are usually less susceptible to viral infections because they often mount stronger immune responses against the viral pathogens than males [51, 52]. Specifically, females elicit stronger innate and adaptive immune responses when compared to male counterpart. This may be responsible for the lower inflammation and reduced HBV/HDV coinfection, thus low HBeAg and HbsAg seropositivity in females [51-54].

The biochemical analysis of subjects from our study revealed more elevated ALT and AST in patients with HBV/HDV co-infection than those with HBV monoinfection. Although the clinical presentations of our study subjects were not evaluated, similar studies corroborated with our findings where they observed HBV/ HDV-co-infected patients had elevated ALT concentrations than those with HBV mono-infection indicating more fibrosis in 4\% [55] and cirrhosis and HCC occurrence in $2.8 \%$ of the patients [56].

Indeed, this study is not without possible limitation. Aside from quantifying the serum AST, ALT and alkaline phosphatase level, other synthetic functions of the liver such as total proteins, albumin and prothrombin 
concentration were not tested. These would have provided more information about the extent of hepatological injuries induced by HDV/HBV co-infection.

\section{Conclusion}

The prevalence of 3.3\% HDV infection in our study area can be considered low; however, there is the need for a more extensive study to understand the disease progression due to the public health threat from dual infection with HBV and HDV so that they can develop proper and timely intervention and surveillance strategies in order to curb the spread of the infection.

\begin{abstract}
Abbreviations
HBV: Hepatitis B virus; HDV: Hepatitis D virus; HBsAg: Hepatitis B surface antigen; HBsAb: Hepatitis B surface antibody; HBCAg: Hepatitis B core antigen; HBeAg: Hepatitis B envelop antigen; HBeAb: Hepatitis B envelop antibody; ALT: Alanine amino transferase; AST: Aspartate amino transferase; ALP: Alkaline phosphatase; HCC: Hepatocellular carcinoma; IgM: Immunoglobulin M; IgG: Immunoglobulin G; Anti-HBs antibody: Hepatitis B surface antibody; Anti-HDV: Hepatitis D virus antibody
\end{abstract}

\section{Acknowledgements}

The authors appreciate the technical support provided by the hospital and staff of the Immunology laboratory.

\section{Authors' contributions}

B.B.A, overall study implementation coordinator. B.S.O, S.L and I.U.I conceived the study. I.M.K, B.W.G, O.O.S, J.S.D, H.M.I, and B.A.D oversaw the implementation of the study. S.L and I.U.I performed the analysis, and B.B.A, S.L, I.N.A and B.S.O wrote the original draft. All authors read and approved the final manuscript.

\section{Funding}

No funding

\section{Availability of data and materials}

All data associated with this article will be made available upon request via the corresponding author.

\section{Ethics approval and consent to participate}

This study was approved by the Research Ethics Committee of the University of Maiduguri Teaching Hospital on 2 April 2019; reference number of approval, HREC/ADM/UMTH/2019/0026. All patients included in this study gave written informed consent to participate in this research.

\section{Consent for publication}

All patients included in this research gave written informed consent to publish the data contained within this study.

\section{Competing interests}

The authors declare that they have no competing interests.

\section{Author details}

${ }^{1}$ Department of Microbiology, School of Sciences, Federal University of Technology, Akure, Ondo State, Nigeria. ${ }^{2}$ Department of Medical Laboratory Science, College of Medical Science, University of Maiduguri, Maiduguri, Borno State, Nigeria. ${ }^{3}$ Department of Medicine, University of Maiduguri Teaching Hospital, Maiduguri, Borno State, Nigeria. ${ }^{4}$ Department of Microbiology, Faculty of Science, University of Maiduguri, Maiduguri, Borno State, Nigeria. ${ }^{5}$ WHO National Polio/ITD Laboratory, University of Maiduguri Teaching Hospital, Maiduguri, Borno State, Nigeria. ${ }^{6}$ Department of Immunology, University of Maiduguri Teaching Hospital, Maiduguri, Borno State, Nigeria. ${ }^{7}$ Department of Medical Laboratory Science, College of Medical Sciences, Ahmadu Bello University, Zaria, Nigeria.
Received: 18 October 2020 Accepted: 14 January 2021

Published online: 01 February 2021

\section{References}

1. Schweitzer A, Horn J, Mikolajczyk RT, Krause G, Ott JJ (2015) Estimations of worldwide prevalence of chronic hepatitis B virus infection: a systematic review of data published between 1965 and 2013. Lancet 386:1546-1555. https://doi.org/10.1016/S0140-6736(15)61412-X

2. Polaris Observatory Collaborators (2018) Global prevalence, treatment, and prevention of hepatitis B virus infection in 2006: a modelling study. Lancet Gastrornterol Hepatol 3:383-403. https://doi.org/10.1016/S24681253(18)30056-6

3. Wedemeyer $\mathrm{H}$, Negro F (2018) Devil hepatitis D: an orphan disease or largely underdiagnosed? Gut 68(1). https://doi.org/10.1136/gutjnl-2018317403

4. Le Gal F, Dziri S, Gerber A, Alloui C, Ben Abdesselam Z, Roulot D et al (2017) Performance characteristics of a new consensus commercial kit for hepatitis D virus RNA viral load quantification. J Clin Microbiol 55:431-441. https:// doi.org/10.1128/JCM.02027-16

5. Chen H-Y, Shen D-T, Ji D-Z, Han P-C, Zhang W-M, Ma J-F et al (2018) Prevalence and burden of hepatitis $D$ virus infection in the global population: a systematic review and meta-analysis. Gut 68(3):512-521. https://doi.org/10.1136/gutjnl-2018-316601

6. Miao Z, Zhang S, Ou X, Li S, Ma Z et al (2019) Estimating the global prevalence, disease progression and clinical outcome of hepatitis delta virus infection. J Infect Dis 221(10):1677-1687. https://doi.org/10.1093/infdis/jiz633

7. Stockdale AJ, Kreuels B, Henrion MRY, Giorgi E, Kyomuhangi I, Geretti AM (2018) Hepatitis D prevalence: problems with extrapolation to global population estimates. Gut 69(2):396-397. https://doi.org/10.1136/gutjnl2018-317874

8. Taylor JM (2006) Structure and replication of hepatitis delta virus RNA. Curr Top Microbiol Immunol 307:1-23. https://doi.org/10.1007/3-540-29802-9_1

9. Sureau C, Negro F (2016) The hepatitis delta virus: replication and pathogenesis. J Hepatol 64(1):S102-S116. https://doi.org/10.1016/j.jhep.2016. 02.013

10. Botelho-Souza LF, Vasconcelos MPA, dos Santos ADO, Salcedo JMV, Vieira DS (2017) Hepatitis delta: virological and clinical aspects. Virol J 14:177. https://doi.org/10.1186/s12985-017-0845-y

11. Fattovich G, Giustina G, Schalm SW, Hadziyannis S, Sanchez-Tapias J, Almasio P et al (1995) Occurrence of hepatocellular carcinoma and decompensation in western European patients with cirrhosis type B. the EUROHEP study group on hepatitis B virus and cirrhosis. Hepatology 21:7782. https://doi.org/10.1002/hep.1840210114

12. Niro GA, Smedile A (2012) Current concept in the pathophysiology of hepatitis delta infection. Curr Infect Dis Rep 14:9-14

13. Smedile A, Farci P, Verme G, Caredda F, Cargnel A, Caporaso N et al (1982) Influence of delta infection on severity of hepatitis B. Lancet 2:945-947

14. Opaleye OO, Japhet OM, Adewumi OM, Omoruyi EC, Akanbi OA, Oluremi AS, Wang B, Hv T, Velavan TP, Bock CT (2016) Molecular epidemiology of hepatitis D virus circulating in southwestern Nigeria. Virol J 13:61

15. Bergmeyer HU, Horder M, Rej R (1986) Approved recommendation (1985) on IFCC methods for the measurement of catalytic concentration of enzymes. Part 2 \& 3 IFCC methods for alanine and aspartate aminotransferase. J Clin Chem Biochem 24:497-508

16. Tietz NW (1983) Liver function tests and the objective evaluation of the patient with liver disease. J Clin Chem Biochem 21:731-748

17. Ajayi BB, Moses AE, Denue BA, Bassi PU, Dayer AD, Samuel JO, Gashau W (2013) A 5-year review of hepatitis B and C viral infection in person living with HIV in the north-East Nigeria. J Med Res Pract 2(9):251-255

18. Stockdale AJ, Kreuels B, Henrion MRY, Giorgi E, Kyomuhangi I, Geretti AM (2020) Hepatitis D prevalence: problems with extrapolation to global population estimates. Gut 69(2):396-397

19. Mbaawuaga EM, Iroegbu CU, Ike AC (2014) Hepatitis B virus (HBV) serological patterns in Benue state, Nigeria. Open J Med Microbiol 4:1-10

20. Akande KO, Fowotade A, Adekanmbi O (2020) The effect of hepatitis D coinfection on the immunologic and molecular profile of hepatitis B in asymptomatic chronic hepatitis B patients in Southwest Nigeria. J Immunoassay Immunochem 41(3):272-280. https://doi.org/10.1080/ 15321819.2020.1728542

21. Adesina OA, Japhet $\mathrm{MO}$ (2017) Hepatitis delta virus in patients referred for malaria parasite test in Ile-Ife, Nigeria. J Med Phys Biophys 36(1):34-38 
22. Waiya SA, Taura DW, Shehu AA, Yahaya SM, Ali M, Garba M (2018) Prevalence of hepatitis D virus antigens among sero-positive hepatitis $B$ surface antigen ( $\mathrm{HBsAg}$ ) patients attending Aminu Kano teaching hospital (AKTH), Kano. Arch Immunol Allergy 1(2):67-74

23. Khair OMM, Enan KA, Hussien MO, Mohammed AA, Bozdayi MA, Karatayli E et al (2016) Seroprevalence and molecular detection of hepatitis delta virus (HDV) among hemodialysis patients and blood donors in a cross-sectional study in Khartoum State. Int J Infect Sudan 3(3):e35391

24. Mudawi HM, Yousif BA (2007) Fulminant hepatic failure in an African setting: etiology, clinical course, and predictors of mortality. Dig Dis Sci 52(11):3266-3269. https://doi.org/10.1007/s10620-006-9730-z

25. Amougou MA, Noah DN, Moundipa PF, Pineau P, Njouom R (2016) A prominent role of hepatitis $D$ virus in liver cancers cumented in Central Africa. BMC Infect Dis 16:647. https://doi.org/10.1186/s12879-016-1992-2

26. Stockdale AJ, Chaponda M, Beloukas A (2017) Prevalence of hepatitis D virus infection in sub-Saharan Africa: a systematic review and meta-analysis. Lancet Glob Health 5(10):e992-e1003. https://doi.org/10.1016/S2214109X(17)30298-X

27. Davaalkham D, Ojima T, Uehara R (2006) Hepatitis delta virus infection in Mongolia: analyses of geographic distribution, risk factors, and disease severity. Am J Trop Med Hyg 75(2):365-369

28. Mansour W, Bollahi M-A, Hamed C-T, Brichler S, Le Gal F, Ducancell A et al (2012) Virological and epidemiological features of hepatitis delta infection among blood donors in Nouakchott, Mauritania. J Clin Virol 55:12-16

29. Ziaee M, Azarkar G (2013) Prevalence of hepatitis D virus infection among patients with chronic hepatitis B attending Birjand hepatitis clinic (east of Iran). Hepat Mon 13:e11168

30. Nguyen HM, Sy BT, Trung NT, Hoan NX, Wedemeyer H, Velavan TP (2017) Prevalence and genotype distribution of hepatitis delta virus among chronic hepatitis B carriers in Central Vietnam. PLoS One 12(4):e0175304

31. Nwokediuko SC, ljeoma U (2009) Seroprevalence of antibody to HDV in Nigerians with hepatitis B virus-related liver diseases. Niger J Clin Pract 12: 439-442

32. Ahmed MA, Sheemy MSA, Sedky N, Esmat G, Gomaa AA (2016) Study of the impact of hepatitis $D$ virus infection on chronic hepatitis $B$ virus patients in Egypt. Int J Curr Microbiol App Sci 5(2):449-458

33. Fouad R, Abdo M, Eldeen HG, Sabry D, Atef M, Ahmed R, Zayed N (2016) Influence of delta virus infection on the virologic status in Egyptian patients with chronic hepatitis B virus genotype D. J Med Virol 88(5):837-842

34. Sy BT, Ratsch BA, Toan NL, Song le H, Wollboldt C, Bryniok A et al (2013) High prevalence and significance of hepatitis $D$ virus infection among treatmentnaive HBsAg-positive patients in northern Vietnam. PLoS One 8:e78094

35. Andrade ZA, Lesborders JL, Ravisse P (1992) Fulminate hepatitis with microvescicular steatosis (a histological comparison of cases occurring in Brazil-Labrea hepatitis- and in Central Africa-Bangui hepatitis). Rev Soc BrasMed Trop 25:155-160

36. Noubissi-Jouegouo L, Atsama MA, Ngoupo PAT, Monamele CG, Ngono L, Njouom R (2019) Evolutionary trends in the prevalence of anti-HDV antibodies among patients positive for HBsAg referred to a national laboratory in Cameroon from 2012 to 2017. BMC Res Notes 12:417. https:// doi.org/10.1186/s13104-019-4460-4

37. Pépin J, Lavoie M, Pybus OG, Pouillot R, Foupouapouognigni Y, Rousset D et al (2010) Risk factors for hepatitis C virus transmission in colonial Cameroon. Clin Infect Dis 51:768-776

38. PMR C, Dos $S$, de Matos MA, Pinheiro RS, KAA C (2017) Prevalence, risk factors and hepatitis $B$ immunization: helping fill the gap on hepatitis $B$ epidemiology among homeless people, Goiânia, Central Brazil. Cad Saúde Pública 33:7

39. Heidrich B, Deterding K, Tillmann HL, Raupach R, Manns MP, Wedemeyer H (2009) Virological and clinical characteristics of delta hepatitis in Central Europe. J Viral Hepat 16(12):883-894. https://doi.org/10.1111/j.1365-2893. 2009.01144.x PubMed: 19566789

40. Bahri O, Cheikh I, Hajji N, Djebbi A, Maamouri N, Sadraoui A et al (2006) Hepatitis B genotypes, precore and core promoter mutants circulating in Tunisia. J Med Virol 78(3):353-357. https://doi.org/10.1002/jmv.20554

41. Ouneissa R, Bahri O, Alaya-Bouafif NB, Chouaieb S, Ben Yahia A, Sadraoui A et al (2012) Frequency and clinical significance of core promoter and precore region mutations in Tunisian patients infected chronically with hepatitis B. J Med Virol 84(11):1719-1726. https://doi.org/10.1002/jmv.23394

42. Wang CX, Lu YQ, Qi P, Chen LH, Han JX (2010) Efficient inhibition of hepatitis $\mathrm{B}$ virus replication by hepatitis delta virus ribozymes delivered by targeting retrovirus. Virol J 7:61. https://doi.org/10.1186/1743-422X-7-61
43. Song C, Wu M, Wang X, Dong Q, Tang R, Fan X (1996) Correlation between hepatitis delta virus infection and heptitis B virus serum markers. World J Gastroenterol 2(4):230-231

44. Knipe DM, Howley P (2013) Fields virology. Wolters Kluwer Health/ Lippincott Williams \& Wilkins, Philadelphia

45. Nicoletta P, Daniel L (2002) Hepatitis BWorld Health Organization. WHO/ CDS/CSR/LSR/LYO/2002.2. http://www.who.int/emc

46. Thomas HC, Lemon SM, Zuckerman AJ (2005) Viral hepatitis. Blackwell Pub, Malden

47. Hughes SA, Wedemeyer H, Harrison PM (2011) Hepatitis delta virus. Lancet 378(9785):73-85

48. Giannini EG, Testa R, Savarino V (2005) Liver enzyme alteration: a guide for clinicians. CMAJ. 172(3):367-379

49. Lago BV, Mello FCA, Barros TM et al (2018) Hepatitis D infection in Brazil: prevalence and geographical distribution of anti-Delta antibody. J Med Virol:1-6. https://doi.org/10.1002/jmv.25196

50. Madejon A, Romero M, Hernandez A et al (2016) Hepatitis B and D viruses replication interference: influence of hepatitis $B$ genotype. World J Gastroenterol 22:3165-3174

51. Gleicher N, Barad DH (2007) Gender as risk factor for autoimmune diseases. J Autoimmun 28(10):1-6

52. Rubtsov AV, Rubtsova K, Kappler JW, Marrack P (2010) Genetic and hormonal factors in female-biased autoimmunity. J Autoimmun Rev 9(7): 494-498

53. Klein SL, Roberts CW (2015) Sex and gender differences in infection and treatments for infectious diseases. Springer International Publishing, Zurich.

54. Berghofer B, Frommer T, Haley G, Fink L, Bein G, Hackstein H (2006) TLR7 ligands induce higher IFN-alpha production in females. J Immunol 177(8): 2088-2096

55. Ho E, Deltenre P, Nkuize M, Delwaide J, Colle I, Michielsen P (2013) Coinfection of hepatitis $B$ and hepatitis delta virus in Belgium: a multicenter BASL study. Prospective epidemiology and comparison with HBV monoinfection. J Med Virol 85(9):1513-1517

56. Romeo R, Del Ninno E, Rumi M (2009) A 28-year study of the course of Hepatitis Delta infection: a risk factor for cirrhosis and hepatocellular carcinoma. Gastroenterol 136(5):1629-1638

\section{Publisher's Note}

Springer Nature remains neutral with regard to jurisdictional claims in published maps and institutional affiliations.

\section{Submit your manuscript to a SpringerOpen ${ }^{\circ}$ journal and benefit from:}

- Convenient online submission

- Rigorous peer review

- Open access: articles freely available online

High visibility within the field

- Retaining the copyright to your article

Submit your next manuscript at $>$ springeropen.com 